\title{
Recent changes in Spanish housing policies: subsidized owner-occupancy dwellings as a new tenure sector?
}

\author{
Joris Hoekstra • Iñaki Heras Saizarbitoria • \\ Aitziber Etxezarreta Etxarri
}

Received: 26 September 2007/ Accepted: 19 June 2009/Published online: 24 November 2009

(C) The Author(s) 2009. This article is published with open access at Springerlink.com

\begin{abstract}
The conventional model of social housing in Spain is a peculiarity within European housing policy, in that it is almost entirely owner-occupied. Subsidized owneroccupancy housing maintains the status of social housing for a set number of years, during which time it cannot be sold against market prices. After that period, its status changes, and the housing concerned becomes part of the free housing market. However, recent developments in Spanish housing policy suggest that this model might change in the future. In some Spanish regions, subsidized owner-occupancy housing is now considered as a separate and permanent tenure category and not as a temporal subsidy arrangement. This paper discusses the background and the possible implications of this new policy perspective.
\end{abstract}

Keywords Spain $\cdot$ Housing policy $\cdot$ Subsidized owner-occupancy housing

\section{Introduction}

Spain is a country of homeowners. Of all Spanish dwellings, $81 \%$ is owner-occupied, $11 \%$ belongs to the rental sector and $8 \%$ belongs to the category 'other' (for example, dwellings that are provided rent free). The large majority of the Spanish rental dwellings is owned by individual private landlords. The share of the social or subsidized rental sector is very limited. Nevertheless, this does not mean that there is no social housing in Spain. In contrast with most other European countries, social housing in Spain is mainly delivered through the owner-occupancy sector.

\footnotetext{
J. Hoekstra ( $\bowtie)$

OTB Research Institute/Delft University of Technology, P.O. Box 5030, 2600 GA Delft, The Netherlands e-mail: j.s.c.m.hoekstra@tudelft.nl

I. Heras Saizarbitoria · A. Etxezarreta Etxarri Universidad del País Vasco, Euskal Herriko Unibertsitatea, San Sebastian, Donostia, Spain e-mail: i.heras@ehu.es
}

\section{A. Etxezarreta Etxarri \\ e-mail: aitziber.etxezarreta@ehu.es}


From 1998 till 2007, the Spanish housing market has been characterized by a housing construction boom and by substantial house price increases. These developments were positive for housing developers and existing homeowners (insiders), but they have caused serious accessibility and affordability problems for first-time buyers (outsiders). Since 2008, the Spanish housing market has entered a period of crisis; the housing production rate, the number of transactions and the house prices have seriously decreased. However, at the moment of writing, it is still too early to assess the long-term impacts of this housing crisis.

Traditionally, social housing in Spain is mainly provided through subsidized owneroccupied dwellings that are sold at below-market prices to households with low and middle incomes. For a limited number of years, during the so-called qualification period, these dwellings keep a protected status, which means that they may not be sold against market prices. Only when the qualification period has expired does the housing concerned become part of the 'normal' housing stock. Recently, there have been policy changes in some Spanish autonomous regions that make the qualification period much longer than it was before. Consequently, it seems as if the subsidized owner-occupancy sector is developing into a new permanent tenure sector. This paper analyzes the background and the possible implications of this new development. It is structured as follows.

Section 2 analyzes the house price increases and the housing construction boom on the Spanish housing market and the accessibility and affordability problems in which these processes have resulted. This section also briefly touches upon the recent housing market crisis. As such, this section sets the stage for the Sects. 3 and 4 in which the Spanish system of subsidized owner-occupancy dwellings, and the recent changes that took place in this system, are described. Finally, Sect. 5 contains the conclusions and proposes some points for discussion.

\section{The Spanish housing market}

In the last decades, but especially in recent years, the Spanish home-owning sector has been characterized by large house price increases. Especially after the year 2000, the rise was spectacular, with average prices increasing by more than $10 \%$ each year (see Fig. 1). In 2008, however, the growth came to an end; at the moment, the house prices are actually decreasing. According to the Spanish housing market index of Tinsa (2009), house prices dropped by $8.8 \%$ between December 2008 and December 2007. Many analysts (for example BBVA 2009) think this is only the start of a much larger house price reduction.

Spain is not the only European country that has known a large increase in house prices. A similar trend can be observed in countries such as the United Kingdom and the Netherlands. However, in these countries the price increases were mainly caused by limited supply responsiveness. Due to institutional factors, such as strict spatial planning and a complicated regulatory framework, the production of new dwellings could keep pace with the increasing demand for dwellings (see Boelhouwer 2005).

In Spain, the situation has been different. Since 1950, the Spanish housing stock has tripled while the numbRodrier of households has only doubled. Since 2001, more than 500,000 dwellings were built each year (see Fig. 2), whereas the average number of households increased by about 300,000 per year (Rodriguez et al. 2008).

The discrepancy between the growth in the number of households and the growth in the number of the dwellings can be explained by the fact that a significant share of the newly built dwellings is used as a second residence, either by Spanish households or by 


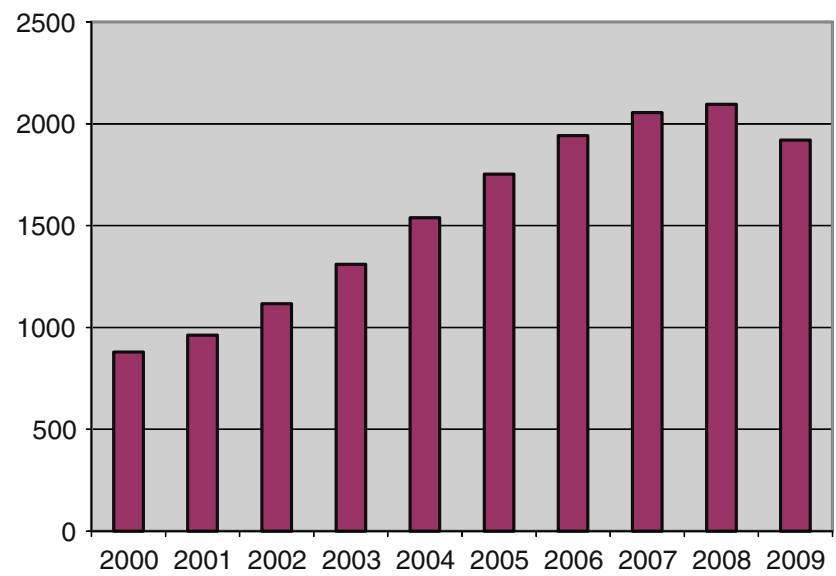

Fig. 1 Average house prices of unsubsidized dwellings (in € per square meter), 2000-2009 (prices for the second quarter of each year). Source: Spanish Statistical Institute (www.ine.es)

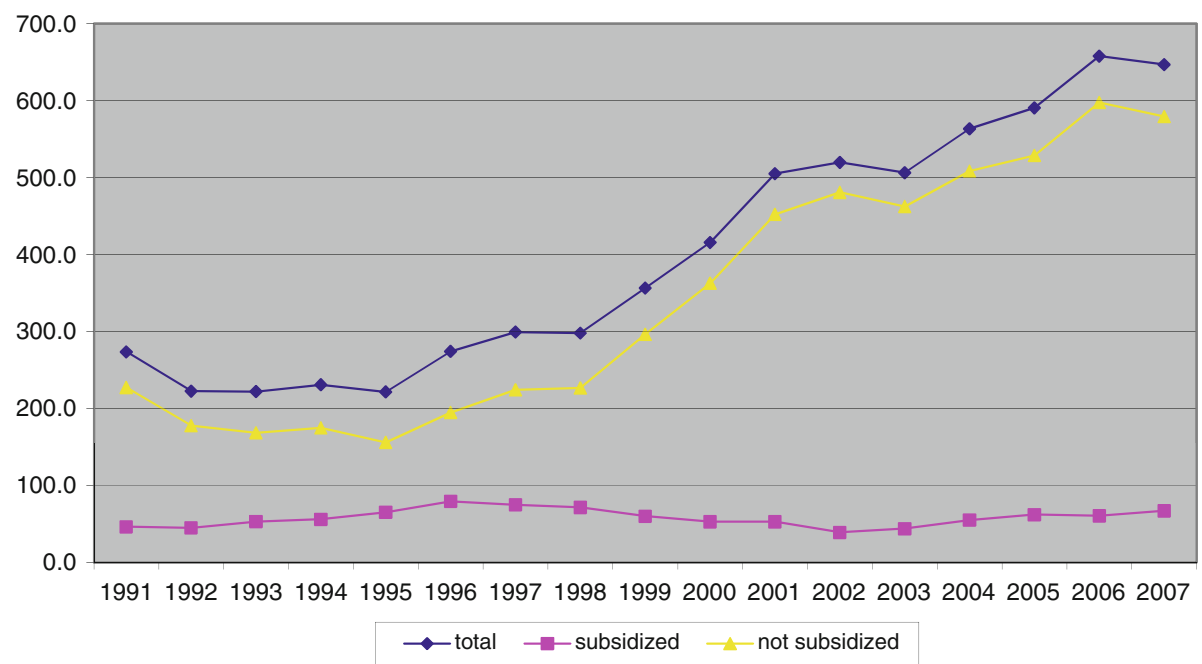

Fig. 2 Number of finished subsidized and unsubsidized dwellings in Spain, 1991-2007 (* 1,000 dwellings). Source: Spanish Ministry of Housing (www.mviv.es)

households from abroad. Furthermore, thousands of properties have been built as personal investments. Once they are completed, these properties often remain uninhabited because - for a variety of reasons, among which speculation is an important factor-they are not sold or placed on the rental market (see Hoekstra and Vakili Zad 2006). Paniagua (2003) has shown that between 1991 and 2001, of every 100 dwellings built, 60 were intended as a main residence and 40 as other types of residential structures. The latter are not related to meeting the need for permanent housing and include, for example, tourist accommodation, investment properties and second homes (see Barke 2008, for a detailed description of second homes in the Spanish housing market). This clearly demonstrates the importance of the investment component in the current Spanish housing market. 
In 2008, the Spanish housing construction boom came to an abrupt end. Although the number of completions remained relatively high (about 450,000 new dwellings were finished in the first 9 months of 2008), the number of housing starts dropped rather dramatically. In 2007, there were 616,000 new housing starts, whereas in the first 9 months of 2008 construction was started on only 246,000 dwellings.

Other housing-related indicators are showing a substantial decrease as well. Between 2007 and 2008, the number of building permits dropped from 651,000 to 215,000 whereas the number of transactions on the housing market decreased from 789,000 to 448,000 (BBVA 2009). Of these 448,000 transactions, 216,000 concerned existing dwellings whereas 232,000 transactions referred to new homes. Since the sale of new dwellings $(232,000)$ is much less than the number of completed new dwellings (still more than a half million in 2008), there is substantial oversupply of newly built dwellings. In March 2008, the excess supply in the Spanish residential sector was estimated at 1.1 million dwellings, and this figure is still rising (BBVA 2009). This development has resulted in a high vacancy rate in the new stock. Many newly built housing complexes are standing almost or sometimes even completely empty.

Obviously, the above figures have had negative effects on the employment situation. In 2008 , unemployment in the Spanish construction sector doubled. At the end of 2008, about 600,000 people in this sector were out of work (data on unemployment per sector from the Spanish statistical institute: www.ine.es).

\subsection{Increasing affordability and accessibility problems}

As a result of the strong increase in house prices, the affordability and accessibility of the home-owning sector has been significantly reduced. Figure 3 shows the 'theoretical effort', an index that has been developed by the Spanish central bank (Banco de España). It shows the percentage of net household income that the median household pays to the mortgage provider in the first year after the acquisition of an unsubsidized dwelling financed with a standard mortgage that covers $80 \%$ of the value of the dwelling, taking into account fiscal deductions. Factors such as the development of house prices and incomes, the interest rate and the conditions of credit providers are (implicitly) taken into account in this index.

The index shows a peculiar development. It was high in 1995 and then dropped in the second half of the 1990s as result of a declining interest rate, better and easier access to mortgages, longer mortgage terms and an increasing share of households with two wageearners. However, due to the house price boom that characterized Spain in the first years of the twentyfirst century, the index started to rise again after 2002, until it reached almost $38 \%$ in 2007.

Based on Fig. 3, we can conclude that the affordability and accessibility of the Spanish unsubsidized owner-occupancy sector has significantly decreased in the last 5 years. As far as this is concerned, it should be noted that the already worrisome indicators in Fig. 3 refer to Spain as a whole. In the regions with the highest house prices (Madrid, Catalonia and Basque country), the accessibility and affordability problem is actually much bigger than the data in the figure suggest.

\subsection{Tensions between stakeholders in the housing market}

Just like the other Mediterranean countries, Spain is a typical example of a home-owning society (Allen et al. 2004; Hoekstra 2005). The Spanish focus on owner-occupation has 


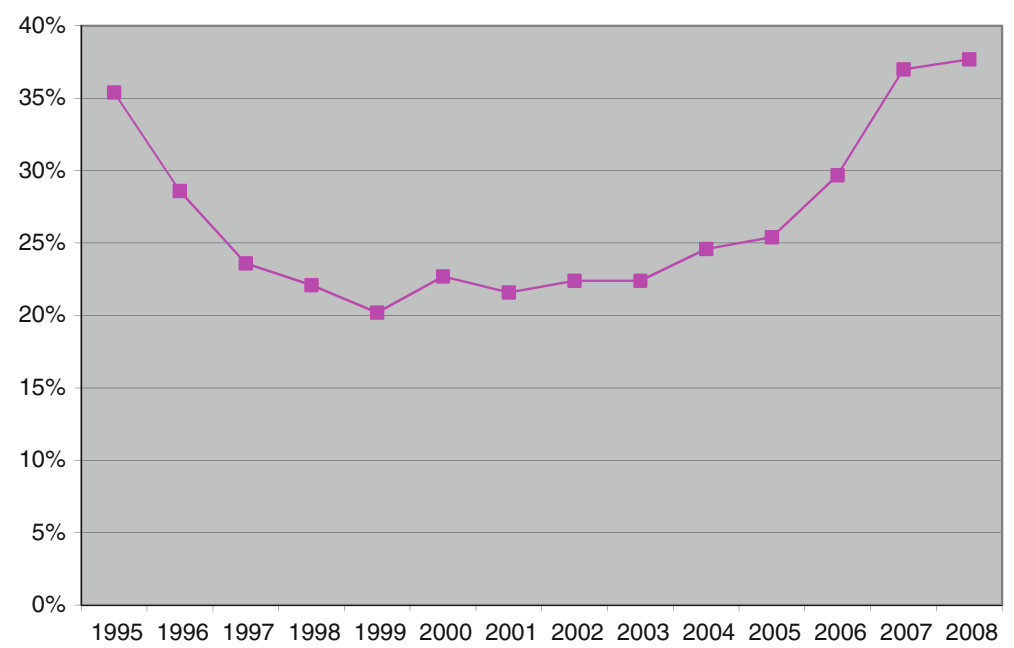

Fig. 3 The 'theoretical effort' indicator for the Spanish owner-occupancy sector, 1995-2008. Source: Banco de España (www.bde.es)

created a complex system of stakeholders, all with their own interests: market insiders and outsiders; the construction industry; and the financial services. The rapid rise in house prices over the last 10 years has heightened tensions between the insiders, for whom the house price increases are favorable, and the outsiders. For a large part of the latter group, the unsubsidized owner-occupancy sector is simply not accessible anymore. The subsidized home-ownership sector provides a flexible means to balance the conflicting stakeholder interests (insiders versus outsiders) and can be adapted to localized market conditions. More details about the Spanish subsidized home-owning dwellings are provided in Sect. 3.

\section{Spanish subsidized owner-occupancy dwellings}

In Spain the right to housing is enshrined in the Constitution (Leal 2004). Article 47 of the Spanish Constitution establishes that "All Spaniards have the right to enjoy decent and adequate housing. The public authorities shall promote the necessary conditions and establish appropriate rules to uphold this right, regulating the use of land in accordance with the general interest to prevent speculation." However, Spanish housing policy has yet been unable to fulfill the provisions of this constitutional mandate, witness the speculative tendencies and the large accessibility and affordability problems described in Sect. 2.

The basic characteristics of Spanish housing policy have their roots in the Francoist period and have remained relatively stable since that time. In fact, one could say that Spain has never had a genuine social housing policy. As highlighted by Trilla (2001), Spanish policies for the provision of housing - both private market housing and social or subsidized housing - have been shaped more by a desire to stimulate economic activity than by social policy per se.

It should be noted that the responsibility for housing policy is shared among the different tiers of government. The national government is in charge of coordinating housing as an economic sector. The Autonomous Communities, depending on the powers granted 
to them in their respective statutes of autonomy, are authorized to modify and complement the central state's housing policies with the help of their own resources. They are responsible for establishing regional housing and land-use regulations, developing and managing their subsidized owner-occupied and rental housing stock, and granting and controlling subsidization of housing investments.

An important characteristic of Spanish housing policy is the complete lack of tenure neutrality in the housing policy instruments. Through both direct (providing subsidized owner-occupancy dwellings) and indirect housing policy interventions (tax policy), the owner-occupancy sector is clearly favored above the rental sector. Moreover, there have been some serious policy disincentives, such as the privatization of the public rental housing stock and a rather strict rent regulation (especially so in the past), to both public and private investment in the rental sector (Leal 2003, 2004). Consequently, the share of the rental sector has been reduced from more than $50 \%$ in 1950 to about $10 \%$ in 2001 .

\subsection{Subsidized home-owning housing}

Spain has a long-standing tradition of providing social or subsidized owner-occupancy housing, generally referred to in Spain by the acronym VPO (Vivienda de Protección Oficia-Officially Protected Housing). As pointed out by Sánchez García and Plandiura (2003), the very concept of subsidized housing, the characteristics - and even the namehave undergone constant changes over time, through a complex series of laws.

After the Civil War, a policy of construction of low-quality public rental housing was adopted in order to meet the growing housing demand in the cities. This demand was caused by large-scale rural-to-urban migration associated with the industrialization process. Nevertheless, this policy did not last long and had a relatively limited impact. This is related to the fact that the Spanish government quickly adopted the policy of selling off the stock of public rental housing.

Since the 1960s, the Spanish government almost uniquely focused its attention on the production of new housing intended for owner-occupancy (Leal 2003; Tatjer 2005; Jurado 2006). As the management of public rental housing generated considerable losses, it was argued that the promotion of owner-occupied housing could result in the construction of more units for the same cost.

The policy of promoting subsidized owner-occupancy housing has since the onset been based on providing assistance to private developers and homebuyers as a form of subsidization specifically designed to boost the construction sector. Within this system, the social circumstances of the recipients were barely taken into consideration and cronyism and fraud prevailed. The new home-ownership society that began to emerge required stable employment in order to assure mortgage repayments; consequently, social and political confrontation eased off.

Still today, direct public intervention in the area of social housing is markedly different in Spain than in most other EU countries, where the majority of social housing tends to be rented. In Spain public housing provision primarily focuses on owner-occupied housing, geared towards medium- and low-income households (households with an income below 5.5 times the minimum wage). It is characterized by a strong involvement of private developers.

The production of subsidized owner-occupancy dwellings is coordinated through a rather complex financing system in which both developers and homebuyers can receive financial support from the government. A part of the subsidized owner-occupancy dwellings is provided by public developers that work on a non-profit basis (usually these are public companies that are tied to the municipal, provincial or regional governments) 
and that are financed with public money. Another part is provided through profit-oriented private developers. Private developers that build subsidized owner-occupancy dwellings can apply for loans (stemming from public finance) with interest rates below the market rate. As a compensation for this, they have to sell the dwellings at regulated prices that are well below the market prices. In other words, the demand for the dwellings that they build is guaranteed, but they have to limit their profits (Ararteko 2007).

There have been considerable fluctuations in the number of subsidized owner-occupancy dwellings built each year (see also Fig. 2). In general, one could say that the production of subsidized owner-occupancy dwellings drops when the housing market is doing well (see also Fig. 2). This is due to the fact that, in such circumstances, it is much more profitable for private developers to invest in non-subsidized owner-occupancy dwellings than to invest in subsidized owner-occupancy dwellings (Sánchez García and Plandiura 2003).

In the past, the construction of subsidized owner-occupancy dwellings always increased in times of crisis (Sánchez Martínez 2002). First of all, this was caused by anti-cyclical investments of the government. Secondly, investing in subsidized owner-occupancy dwellings becomes more attractive for private developers when the economy is performing badly. Although the profit margins in this sector are relatively small, demand is more or less guaranteed and financial support from the government is available. This makes the subsidized owner-occupancy sector a good outlet for risk-averse investments.

\subsection{A temporary social housing model}

An important characteristic of Spanish subsidized owner-occupancy housing is the temporary nature of the subsidization arrangement. Housing developed with the help of public money (called VPO housing) is only considered as subsidized housing for a given period of time: the so-called qualification period. During that period, subsidized owner-occupancy dwellings can only be sold against prices that are determined by the government (generally the price of new subsidized owner-occupancy dwellings). The aim of this is to prevent speculation. When the qualification period expires, the housing concerned loses its status as subsidized housing and is incorporated into the 'normal' housing stock, which implies that it can be sold at market prices. This system dates back to the 1950s and 1960s, when social housing had a qualification period of between 20 and 50 years (Sánchez García and Plandiura 2003). In 1978, a standard qualification period of 30 years was established.

At the beginning of the 1990s, a new form of subsidized owner-occupancy housing with no qualification period was created: Vivienda a Precio Tasado (VPT). The price of this mediumcost housing was lower than the market price but much higher than the price of VPO housing. As mentioned above, the VPT housing was not subject to the 30 -year qualification period that applied to VPO housing. However, recipients of VPT housing who sold the dwelling within 5 years were required to pay any personal subsidies they had received back to the government. Since VPT dwellings could be sold against market prices immediately after purchase, they soon became a profitable object for speculation (Sánchez García and Plandiura 2003).

In 1993, all subsidized owner-occupancy housing provided prior to 1978 was liberalized. In other words, a large part of the stock of VPO housing was retroactively deregulated, being released from the 20- or 50-year protection arrangements and the maximum sales prices applicable during those periods. In 1998, the maximum duration of the qualification period for VPO housing was reduced from 30 to 20 years. During this 20-year qualification period, the sales price of the dwelling was not allowed to exceed the maximum price decided by the government. This maximum price was based on the selling prices of new subsidized owner-occupancy dwellings. Furthermore, if a subsidized 
Table 1 Number of subsidized, formerly subsidized (declassified) and unsubsidized owner-occupancy dwellings in Spanish autonomous regions, 2007

\begin{tabular}{|c|c|c|c|c|c|c|c|}
\hline Region & $\begin{array}{l}\text { Subsidized } \\
\text { dwellings (A) }\end{array}$ & $\begin{array}{l}\% \text { of } \\
\text { total }\end{array}$ & $\begin{array}{l}\text { Non- } \\
\text { subsidized } \\
\text { dwellings (B) }\end{array}$ & $\begin{array}{l}\% \text { of } \\
\text { total }\end{array}$ & $\begin{array}{l}\text { Total } \\
(\mathrm{A}+\mathrm{B})\end{array}$ & $\begin{array}{l}\text { Declassified } \\
\text { subsidized } \\
\text { dwellings } \\
2002-2007\end{array}$ & $\begin{array}{l}\text { As } \% \\
\text { of A }\end{array}$ \\
\hline Andalucía & 598,226 & 14 & $3,689,790$ & 86 & $4,288,016$ & 32,138 & 5 \\
\hline Aragón & 93,871 & 13 & 647,025 & 87 & 740,896 & 5,119 & 5 \\
\hline Asturias & 94,417 & 16 & 500,996 & 84 & 595,413 & 5,138 & 5 \\
\hline Baleares & 26,789 & 5 & 548,503 & 95 & 575,292 & 1,436 & 5 \\
\hline Canarias & 60,707 & 6 & 954,178 & 94 & $1,014,885$ & 3,209 & 5 \\
\hline Cantabria & 33,012 & 10 & 304,035 & 90 & 337,047 & 1,725 & 5 \\
\hline Castilla y León & 166,136 & 10 & $1,491,467$ & 90 & $1,657,603$ & 8,870 & 5 \\
\hline $\begin{array}{l}\text { Castilla-La } \\
\text { Mancha }\end{array}$ & 125,604 & 11 & $1,038,109$ & 89 & $1,163,713$ & 6,527 & 5 \\
\hline Cataluña & 294,207 & 8 & $3,534,819$ & 92 & $3,829,026$ & 15,877 & 5 \\
\hline $\begin{array}{l}\text { Comunidad } \\
\text { Valenciana }\end{array}$ & 413,755 & 14 & $2,623,834$ & 86 & $3,037,589$ & 22,302 & 5 \\
\hline Extremadura & 76,749 & 12 & 562,248 & 88 & 638,997 & 4,013 & 5 \\
\hline Galicia & 106,347 & 7 & $1,401,033$ & 93 & $1,507,380$ & 5,468 & 5 \\
\hline Madrid & 293,307 & 10 & $2,548,045$ & 90 & $2,841,352$ & 14,167 & 5 \\
\hline Murcia & 102,367 & 14 & 642,931 & 86 & 745,298 & 5,572 & 5 \\
\hline Navarra & 57,418 & 19 & 243,963 & 81 & 301,381 & 2,913 & 5 \\
\hline País Vasco & 156,501 & 16 & 826,710 & 84 & 983,211 & 8,112 & 5 \\
\hline La Rioja & 27,997 & 15 & 158,807 & 85 & 186,804 & 1,456 & 5 \\
\hline Ceuta y Melilla & 4,907 & 9 & 47,034 & 91 & 51,941 & 246 & 5 \\
\hline Total & $2,732,317$ & 11 & $21,763,527$ & 89 & $24,495,844$ & 144,288 & 5 \\
\hline
\end{tabular}

Source: Spanish Ministry of Housing (Estimación del parque de viviendas)

dwelling is sold in the first 10 years after purchase, all the personal subsidies that were tied to the VPO regime plus the legal interests have to be repaid to the government.

\subsection{Regional differences}

The share of subsidized owner-occupancy housing differs between the Spanish regions (see Table 1). The lowest percentage of subsidized homeownership can be found in the island regions (Baleares 5\%, Canarias 6\%), the highest in the northern regions of Navarra (19\%) and the Basque country $(16 \%)$. Each year almost $1 \%$ of the subsidized dwelling stock is declassified as the qualification period elapses. As far as this is concerned, there are no clear differences between the various Spanish regions.

\section{Towards a permanent subsidized owner-occupancy sector?}

Because the qualification period for subsidized owner-occupancy housing (VPO housing) is limited in time, the owners of such dwellings have good possibilities to make profits in the longer term. After all, the house prices on the free housing market are much higher than the house prices of subsidized owner-occupancy dwellings. Especially in regions with very 


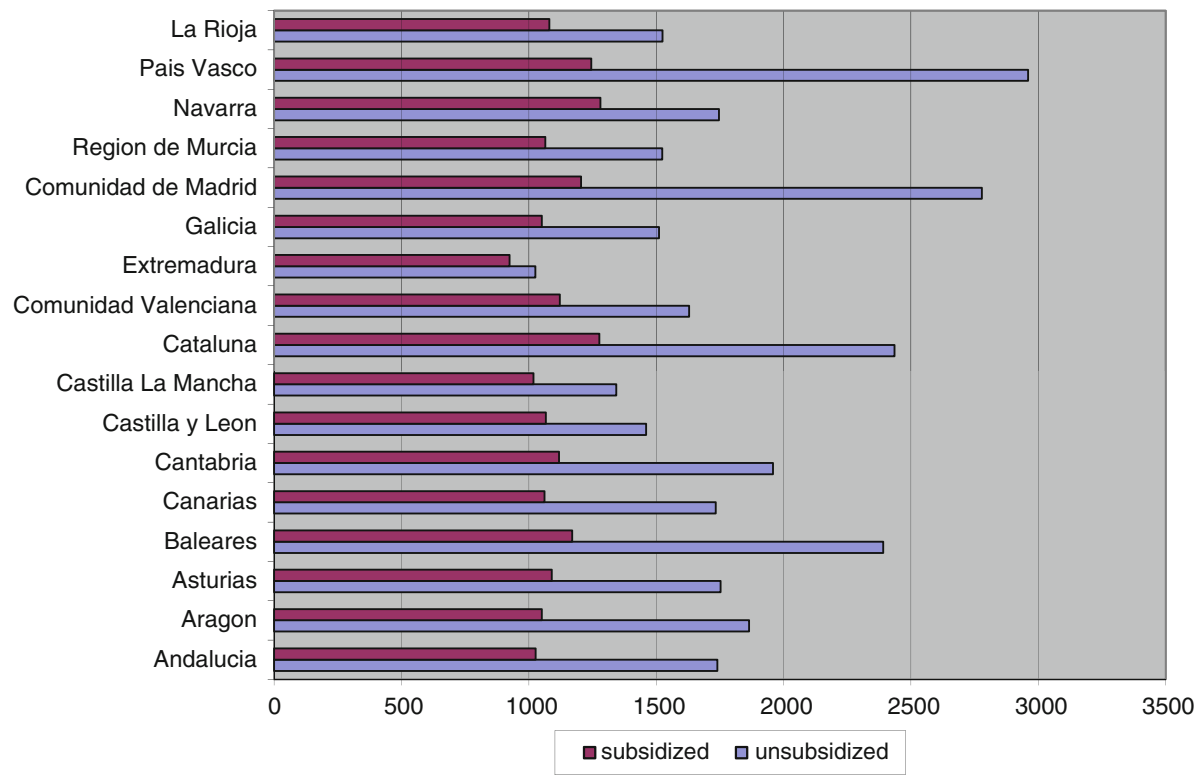

Fig. 4 Prices of unsubsidized and subsidized owner-occupancy dwellings in Spanish autonomous regions, in $€$ per square meter, fourth trimester of 2008. Source: Website of the Spanish Ministry of Housing ( www.mviv.es)

high house prices in the non-subsidized owner-occupancy sector, such as Madrid, Catalonia and the Basque country, the potential for profit-making is substantial (see Fig. 4).

Recently, some steps have been taken towards limiting the temporary aspect of subsidized owner-occupancy housing in Spain. These changes have come about in a social context that is characterized by keen awareness of Spanish public opinion in relation to the issue commonly referred to as 'the housing problem'. Various young people's associations have begun to mobilize, claiming the right of the young to a decent home without being burdened by a high mortgage for the rest of their lives. Furthermore, many consider it unfair that the young (outsiders) have such difficulty finding an affordable dwelling, whereas people who bought a subsidized dwelling 20 or 30 years ago (insiders) can now make large profits.

In our opinion, all these factors have considerably influenced the policy-makers in their decision to begin taking steps towards limiting the temporary nature of subsidized owneroccupancy housing. Indeed, the 2005-2008 Housing and Land Plan established a minimum qualification period of 30 years for traditional social housing (VPOs), which can be changed at the discretion of the Autonomous Communities. The Plan also established that the Autonomous Communities are free to determine the qualification period for medium-cost VPT housing.

If an owner of a subsidized owner-occupancy dwelling wants to sell that dwelling (second-time or subsequent sale), it should be sold to potential buyers who are listed in a register that has been set up by the Autonomous Communities so that fraud can be prevented. ${ }^{1}$ According to the 2005-2008 state plan, second-time and subsequent sales of

\footnotetext{
${ }^{1}$ However, due to the opposition of some of the Autonomous Communities, which claimed they would have difficulty implementing those registers immediately, this measure was not made compulsory in a transitional period, with the Communities being left to establish their own control measures to avoid fraud in the sale of subsidized housing.
} 
subsidized owner-occupancy dwellings are bound to a maximum sales price that is determined by each autonomous region and that is capped by the central government at twice the initial sales price (adjusted in line with the Consumer Price Index). This cap has been criticized, as it still leaves considerable room for profit-making.

\subsection{Regional differences}

Within the regulatory framework described above, the autonomous regions have the freedom to implement their own regulations with regard to the qualification period of subsidized owner-occupancy dwellings (Burón 2006). As far as this is concerned, three types of Autonomous Communities can be distinguished.

1. Autonomous Communities that have opted for permanent or nearly permanent qualification.

2. Autonomous Communities that apply a qualification period of 30 years, in line with the timescale set by the 2005-2008 State Plan.

3. Autonomous Communities that, through different regional varieties of subsidized housing, have reduced the qualification period to below the 30-year benchmark period. This last case includes, for instance, Viviendas de Protección Pública, a form of subsidized rental housing with an option to buy, introduced by the Autonomous Community of Madrid, which can be declassified after 7 years, and the Vivienda Protegida Autonómica, also in the Madrid region, which can be declassified after 15 years.

The first option is chosen in the Autonomous Communities of Catalonia, Asturias, Extremadura and the Basque Country. In 2004, the Autonomous Community of Catalonia established a 90-year qualification period for VPO housing, whereas the Autonomous Community of Extremadura gave all the VPO housing a permanent character. Similarly, the Autonomous Community of Asturias established the qualification of social housing until such time as the property is declared unfit.

The Autonomous Community of the Basque Country deserves separate mention. This region made a pioneering move when it established a permanent qualification of all subsidized owner-occupancy housing in 2002. The background of this is discussed in more detail below.

\subsection{The case of the Basque Country}

The Basque Country (Comunidad Autonoma del País Vasco: CAPV) is the autonomous region with the highest house prices in Spain (see Fig. 4). With a share of $16 \%$ of the total stock of owner-occupancy dwellings, the subsidized home-owning sector is relatively important in this region (see also Table 1). In recent years, the Basque government (as well as the provinces and municipalities in the region) invested rather heavily in the subsidized sector. Between 2001 and 2004, no less than 44\% of all the housing starts in the Basque Country concerned subsidized homeownership dwellings (Ararteko 2007).

Since 2002, subsidized owner-occupancy housing has a permanent status in this autonomous region. Moreover, the Basque government has a first right to buy for all VPO sales on the free market so that they can subsequently reallocate the housing (see Ararteko 2007 for an extensive and detailed description of the Basque policies towards subsidized homeowner housing). 
The above policy measures are widely accepted by Basque society. According to the Survey of Housing Needs and Demand conducted by the CAPV in 2005 (Department of Housing and Social Affairs 2006), the vast majority of the Basque population was in favor of the permanent qualification of social housing. More specifically, $89.7 \%$ of young people seeking their first home and $90.4 \%$ of the households that want to move to another dwelling approved of this initiative.

The sale of subsidized owner-occupancy social housing with limited leasehold is another recent feature of housing policy in the Basque region. For some years now, the bulk of subsidized owner-occupancy housing in the CAPV has been provided under a 75year leasehold arrangement. This means that the government retains the ownership of the land on which housing is built. After 75 years, the units themselves also become the property of the government. This period remains fixed, regardless of any changes of owner. In reality, however, there are few owners of subsidized dwellings who worry about these conditions. Most of these people consider themselves as 'full homeowners' and expect that the strict conditions will be relaxed in the course of time.

Further limitations on the ownership of subsidized owner-occupancy housing are currently under discussion. For example, it has been suggested to review the circumstances of the occupants of subsidized owner-occupancy dwellings at given intervals, in order to ascertain whether there has been any change in their financial and economic situation. If occupants are found to no longer be entitled to continue living in subsidized housing, they will have to give it up (possibly against a compensatory sum of money). ${ }^{2}$ However, until now, this discussion has not resulted in concrete policy measures at the regional level.

Recent housing policy developments in the Basque Country are very much influenced by the current economic and housing crisis, as well as by the fact that there are regional elections in 2009. Given the rising unemployment and the increasing number of people who have problems paying their mortgage, the Basque government has proposed to buy the dwellings, either subsidized or unsubsidized, from people who are in financial problems. The former owner of the dwelling can then keep on living there as a tenant, paying a monthly rent to the Basque government. Moreover, a right to buy applies so that the former owner can repurchase the dwelling when his financial situation improves (information from www.etxebide.net, 2009).

\section{Conclusions and discussion}

This paper has shown that there are some serious problems on the Spanish housing market. Despite the impressive housing production rate, the house prices are very high and there are affordability and accessibility problems for first-time buyers, especially in the more urbanized regions such as Madrid, Catalonia and the Basque Country. For many young households that want to buy a dwelling, the subsidized owner-occupancy sector is the only alternative.

Traditionally, the Spanish subsidized owner-occupancy sector was a temporary sector. As a result of the big price differences with the unsubsidized sector, this offered good possibilities for profit-making once the qualification period had ended. In order to prevent this, various Autonomous Communities have recently developed policies that give the subsidized owner-occupancy sector a more permanent character. Some Autonomous

\footnotetext{
${ }^{2}$ Actually, there is a community in the Basque Country, Getxo, where such a system is already in force.
} 
Communities have now chosen for a permanent or nearly permanent qualification period. This implies that a 'new' permanent or semi-permanent tenure category is being created.

Spain is not the only country with a permanent or semi-permanent subsidized owneroccupancy sector. More or less comparable sectors exist in countries such as the United Kingdom (shared ownership, home buy), Ireland (affordable housing scheme), the United States (Low Equity Housing Cooperatives), and the Netherlands (see Elsinga 2005 for more information on these schemes). Also in some Asian countries, notably in Singapore and Hong Kong, subsidized owner-occupancy dwellings are a common phenomenon (Ronald 2008). All the countries mentioned above have seen large increases in house prices, which have made the homeownership sector less accessible and affordable for starters on the housing ladder. Moreover, most of the countries concerned (with the exception of the Netherlands and to a lesser extent Hong Kong) can be characterized as home-owning societies. Therefore, we tentatively conclude that the emergence of a more or less permanent subsidized homeownership sector is a phenomenon that can primarily be seen in countries that have known a large increase in house price and in which there is a general preference for home-owning. This certainly applies to Spain and even more so to the Basque Country.

\subsection{Discussion}

In our opinion, the more permanent nature of the Spanish subsidized owner-occupancy sector in at least some regions is a positive development. It allows for a fairer and more efficient allocation of government resources. After all, the government subsidies stay in the subsidized sector and are not transferred to a 'random' homeowner.

At the same time, the creation of a permanent subsidized owner-occupancy sector may have consequences for the further development of the housing market in the regions concerned. It can, for example, result in a further reduction of the already relatively low mobility rate. If occupants of subsidized owner-occupied dwellings are not able to accumulate significant assets in their dwelling by taking profit from house prices increases, it will be difficult, as well as financially unattractive, for them to move to an unsubsidized dwelling in a later stage of their life. At the moment, the price difference between subsidized and unsubsidized owner-occupancy dwellings is so large that it is difficult to bridge this gap on the basis of income increases and personal savings alone. Thus, the creation of a permanent subsidized owner-occupancy sector might lead to a compartmentalization of the housing market. It can result in a subsidized owner-occupancy sector on the one hand, an unsubsidized owner-occupancy sector on the other hand, and little interaction between these two segments. In the long run, intergenerational transfers might even pass on the above difference from one generation to another.

This can possibly be prevented by the creation of an intermediary sector. Such a sector already exists in the form of VPT housing, which is more expensive and offers more quality than ordinary subsidized owner-occupancy housing but is still less expensive than the unsubsidized owner-occupancy sector. This VPT housing can possibly function as a bridge between the subsidized owner-occupancy sector (VPO) and the unsubsidized owner-occupancy sector. Nevertheless, we doubt whether this is a real solution since the price differences between VPT housing and unsubsidized housing are still considerable. Thus, the stimulation of VPT housing might as well result in the creation of yet another segment within the Spanish owner-occupancy sector (next to the VPO dwellings and the unsubsidized dwellings). 
Finally, one may wonder how the VPO sector will develop in the current housing market crisis. In the past, the production of subsidized owner-occupancy dwellings increased in times of limited production of unsubsidized owner-occupancy dwellings (see Fig. 2). An increased production of subsidized owner-occupancy dwellings also entails more expenditure by the national or regional governments. In the last decade, the subsidized owner-occupancy dwellings were built with no or few government production subsidies. To a large extent their construction was paid by the proceeds (for either the government or the developers) that resulted from the construction of unsubsidized homeowning dwellings. But in the current context of decreasing house prices and decreasing housing production, such cross-subsidization is not possible anymore. The government will have to step in with extra money if it wants to maintain a steady production of subsidized homeownership dwellings. Also, with the current decrease in house prices, it is difficult to assess at which price the government should buy subsidized homeownership dwellings in the case of a sale of the dwelling during the qualification period.

In connection with this, one could ask whether it is really desirable to strive for a high production of subsidized owner-occupancy dwellings in the future. In Sect. 2 we have shown that the Spanish housing market crisis has partly been caused by an oversupply of dwellings. More than one million newly built dwellings are currently empty. Both the Spanish government and various regional governments have taken initiatives that aim to add vacant dwellings to the rental sector. We think that it might be a good idea to extend this strategy to the home-owning sector. The government could buy empty unsubsidized houses from developers or households and transform them into VPO housing. This is not a solution that can be applied anywhere and anytime, but in some cases it should definitely be considered. In our opinion, a sensible VPO strategy not only focuses on new housing construction but also takes into account the developments in the existing housing stock.

Acknowledgments The authors wish to acknowledge the financial assistance of the Dutch government through the Habiforum Program Innovative Land Use as well as that of Delft University of Technology through the Delft Center for Sustainable Urban Areas.

Open Access This article is distributed under the terms of the Creative Commons Attribution Noncommercial License which permits any noncommercial use, distribution, and reproduction in any medium, provided the original author(s) and source are credited.

\section{References}

Allen, J., Barlow, J., Leal, J., Maloutas, T., \& Padovani, L., (2004). Housing and welfare in southern Europe. London: Blackwell.

Ararteko, (2007). Las políticas públicas de vivienda dirigidas a la población joven de la CAPV, [Public housing policies aimed at the young population in the Autonomous Community Basque country] report published by Ararteko. Vitoria-Gasteiz, Spain: Ombudsman of the Basque Autonomous Region.

Barke, M. (2008). Second homes in the Spanish housing market: One market or two. Journal of Housing and the Built Environment, 23, 277-295.

BBVA. (2009). Real Estate Watch, BBVA Economic Research Department. 19 December 2008.

Boelhouwer, P. J. (2005). The incomplete privatization of the Dutch housing market: Exploding house prices versus falling house-building output. Journal of Housing and the Built Environment, 20(4), 363378.

Burón, J. (2006). Las reservas de suelo para vivienda protegida: Lecciones del caso de Vitoria-Gasteiz [Land reservations for subsidized homeownership dwellings. Lessons from Vitoria-Gasteiz] Arquitectura, Ciudad y Entorno, vol. 1, No. 2. 
Department of Housing and Social Affairs. (2006). Necesidades y demanda de vivienda en la CAPV. Encuesta de coyuntura, informe de resultados 2005 [Housing need in the Basque autonomous region. Results for 2005] Vitoria-Gasteiz, Spain.

Elsinga, M. (2005). Affordable and low-risk home ownership. In P. Boelhouwer, J. Doling, \& M. Elsinga (Eds.), Home ownership, getting in, getting from, getting out. Housing and urban policy studies 29. Delft: Delft University.

Hoekstra, J. (2005). Is there a connection between welfare state regime and dwelling type. An Exploratory Statistical Analysis Housing Studies, 20(3), 475-495.

Hoekstra, J., \& Vakili Zad, C. (2006). High vacancy rates and high house prices. A Mediterranean paradox, Paper for the ENHR 2006 conference in Slovenia.

Jurado, T. (2006). El creciente dinamismo familiar frente a la inflexibilidad del modelo de vivienda español. Cuadernos de Información Económica, 193, 117-126.

Leal, J. (2003). Spain. In J. Doling \& J. Ford (Eds.), Globalisation and home ownership. Experiences in eight member states of the European Union. Delft: Delft University.

Leal, J. (2004). El diferente modelo residencial de los países del sur de Europa: el mercado de viviendas, la familia y el estado [The different residential model of the Southern European countries: the housing market, the family and the state]. Arxius, No. 10, Universidad de Valencia, Spain (available at www.uv.es).

Paniagua, J. L. (2003). La necesidad de intervención pública en materia de suelo y vivienda, [The need for public intervention with regard to land and housing]. Papeles de la FIM, especial Suelo y vivienda, No. 20, Madrid, Spain.

Rodriguez, J., Fellinger, E., \& Dominguez, J. (2008). Hogares en España. Proyecciones 2001-2012 [Households in Spain. Prognosis 2001-2012], Ministerio de Vivienda, www.mviv.es.

Ronald, R. (2008). The ideology of home ownership: The role of housing in homeowner societies. London: Palgrave.

Sánchez García, A., \& Plandiura, R. (2003). La provisionalidad del régimen de protección oficial de la vivienda pública en España [The provisional character of subsidized homeownership housing in Spain] Scripta Nova. Online Geography and Social Sciences Journal, vol. VII, No. 146(090). Spain: Universidad de Barcelona.

Sánchez Martínez, M. T. (2002). La política de vivienda en España: análisis de sus efectos redistributivos [Housing policy in Spain. An analysis of its redistributive effects]. Granada: Universidad de Granada.

Tatjer. (2005). La Vivienda obrera en España de los siglos XiX y XX: de la promoción privada a la promoción pública (1853-1975), [Working-class housing in Spain in the 19th and 20th century: from private intervention to public intervention] Scripta Nova. Revista electrónica de geografía y ciencias sociales, vol. IX, No. 194 (23).

TINSA. (2009). Notas de Coyuntura Inmobiliaria, Mercado Residencial [Notes on the situation on the residential property market], $3^{\circ}$ trimester de 2008.

Trilla, C. (2001). La política de vivienda en una perspectiva europea comparada [Housing policy in a European comparative perspective] Colección Estudios Sociales No. 9, Fundación "La Caixa". Spain: Barcelona. 